\title{
SENSORY AND PHYSIOLOGICAL QUALITY OF ARABIC COFFEE UNDER DIFFERENT FERMENTATION TIMES
}

\author{
QUALIDADE SENSORIAL E FISIOLÓGICA DO CAFÉ ARÁBICA SOB DIFERENTES \\ TEMPOS DE FERMENTAÇÃO
}

\author{
Kênia Barbosa do CARMO'ㅍ Jéssica Conceição Barbosa do CARMO²; \\ Marcelo Rodrigo KRAUSE ${ }^{3}$; Guilherme PETERLE ${ }^{4}$. \\ 1. Engenheira Agrônoma, Instituto Federal do Espírito Santo- Campus Santa Teresa, IFES, Santa Teresa, ES, Brasil. \\ keniabcarmo@gmail.com; 2. Engenheira Agrônoma, Universidade Federal de Viçosa - Campus Viçosa, Viçosa, MG, Brasil; \\ 3. Doutorando em Fitotecnia, Universidade Federal de Viçosa - Campus Viçosa, Viçosa, MG, Brasil; 4. Mestrando em Produção \\ Vegetal, Universidade Estadual do Norte Fluminense "Darcy Ribeiro" - Campus Leonel Brizola, Campos dos Goytacazes, RJ, Brasil.
}

\begin{abstract}
The value of coffee presents a significant increase influenced by the improvement of the beans quality, so that a coffee made by beans with an inferior quality has a lower acceptance in the market and a reduction in therms of commercialization value. The different time of fermentation of the coffee in water can give rise to different beverage and physiological quality of its seeds, and may interfere in its commercialization value and in the production of seedlings in nurseries. The target of this study was to identify the best time of fermentation of the beans and seeds of Arabic coffee in the region of Mutum-MG, aiming to obtain a better quality of the drink and a better physiological quality of the seeds. The experimental design was completely randomized with seven treatments, $0,6,12,18,24,30$ and 36 hours of fermentation in water. Four replicates per treatment were used. Each repetition consisted in ten liters of coffee. The samples were submitted to a drying process in covered suspended terrarium until reaching $12 \%$ moisture. The evaluations consisted in the realization of these sensorial analysis (AS); \% water content (\%U); electrical conductivity (EC); first germination count (FCG); percentage of germination (\%G); total fresh mass (TFM); total dry mass (TDM) and radicle length (RL). The 18 hours fermentation time provided a better quality of coffee drink obtaining a score of 84 points and also resulted in a higher physiological quality of the seeds. Excess fermentation impaired the quality of the drink and physiological quality.
\end{abstract}

KEYWORDS: Postharvest. Beverage. Specialty coffee.

\section{INTRODUCTION}

The coffee culture (Coffea arabica L.) is one of the most important agricultural products in the international market because it is one of the main agricultural products of exportation of the country, adding a considerable volume of resources to the national commercial scale (APARECIDO; ROLIM; SOUZA, 2015).

Brazil is the greatest world coffee producer and exporter and the second greatest world coffee consumer, although it only uses $0.86 \%$ of the Explored Area (256.8 million/ha), whose coffee cultivation comprise 2.2 million hectares (CONAB, 2017).

According to Conab (2017), the Brazilian production in 2017 was of 44.97 million of processed bags, from which 34.25 million of them were arabica coffee bags and 10.72 million of conilon coffee. The state of Minas Gerais produced 24.45 million bags of arabica coffee, from which $6,257.7$ thousand bags of arabica coffee were produced in the region of the Mineira Zona da Mata.

The beverage's quality is affected by several factors, such as the species, handling, weather, and postharvest procedures (GIOMO, 2012).

The choice of the processing and drying methods vary considerably among producers, depending especially on technological, climatic, and economic features and on the demands of the consuming market (ISQUIERDO et al., 2011).

In Brazil, coffee is dry processed, which consists on drying the whole fruit, that is with its exocarp (peel), mesocarp (pulp and mucilage), and endocarp (parchment), resulting in what is known as natural coffee. As for the wet processing method, which results in coffee in parchment, there are several ways to perform it: by mechanically removing the peel and part of the mucilage, resulting in peeled coffee; by mechanically removing the peel while the mucilage is removed by biological fermentation, resulting in depulped coffee; and by mechanically removing the peel and 
the mucilage, resulting in demucilaged coffee (BORÉM, 2008). The wet processing consists in removing bark, pulp and / or mucilage from the mature fruit, which are favorable substrates to the development of microorganisms that can provoke fermentations that are detrimental to the final quality of the product (MALTA, 2011; MALTA; CHAGAS; CHALFOUN, 2008).

The wet processing, in addition to reducing the mass of coffee that will be dried, decreases the volume of the coffee to be benefited and reduces the risks of development of microorganisms associated to the fruits, responsible for undesirable fermentations (BORÉM, 2008; MATIELLO, 2002).

Natural fermentation is the most used method and occurs essentially by hydrolysis reactions that facilitate the removal of mucilage during the washing process. In this process the seeds remain immersed in water, so that the mucilage is completely liberated, for a period between 18 to 24 hours, at a temperature above 20 ${ }^{\circ} \mathrm{C}$, which does not affect the physiological quality of the seed, afterwards the seeds are washed in water mains (DIAS; BARROS, 1993; REIS; CUNHA, 2010).

During the natural fermentation process fermentation time is questioned, because if prolonged, biochemical transformations can occur, which can alter the chemical composition of the seed, generating as a consequence drastic damages to its quality, affecting the percentage of the emerged seedlings (AVALLONE et al, 2001; AVALLONE et al., 2002; LIMA et al, 2009).

The coffee beans (Coffea arábica L.) are obtained in the degumming process, which consists of removing the fruit's peel and mucilage during its cherry stage (seven to eight months after its anthesis). The fruits are degummed, their epicarps are removed, and the seeds are released. This process can be performed through several methods, such as chemical, mechanical, or through the natural fermentation method (REIS;CUNHA, 2010; NEY et al., 2015). The metabolic processes are directly related to germination processes that occur in the fruits after the harvest (SELMAR et al., 2006).

The coffee's controlled fermentation can result in beverages with special smell and taste sweet, citric, fruity, and roasted, which add value and coherence to the product's quality. In the coffee fermentation technology, we need to control the temperature, the water's quality, the coffee's quality and health, and the fermentation process time (CECAFÉ, 2015).
The target of this study was to identify the best fermentation time for beans and seeds of Arabica coffee in the region of Mutum-MG, aiming to obtain a better quality of the drink and a better seeds' physiological quality.

\section{MATERIAL AND METHODS}

The experiment was installed in the city of Mutum-MG, of the district of Imbiruçu, at the altitude of $868 \mathrm{~m}$ (latitude $20^{\circ} 10^{\prime} 8.65^{\prime} \mathrm{S}$, longitude $\left.41^{\circ} 25^{\prime} 0.95^{\prime \prime}\right)$. We employed arabica coffee fruits of the agricultural year of 2014/2015, of the IAC Catuaí 44 Red cultivar, which has been standing out by its elevated adaptation in the region.

The fruits were harvested during their cherry stage and mechanically depulped in the same day. The biological fermentation was performed in a polyethylene box, using coffee beans and drinkable water.

The samples were identified, submitted to a drying process in a suspended platform, which was covered until it reached $12 \%$ of humidity, and stored in raffia bags.

The experimental design employed was entirely randomized, with four repetitions. The treatments consisted of the following fermentation hours in water: $6,12,18,24,30$, and 36 hours, and a control sample without fermentation. Each batch was composed of ten liters of coffee.

The evaluations consisted in realizing some sensorial analysis (AS); \% humidity ( $\left.\begin{array}{ll}\% & \mathrm{U}\end{array}\right)$; electrical conductivity (EC); first germination count (FCG); percentage of germination $(\% \mathrm{G})$; total fresh mass (TFM); total dry mass (TDM) and radicle length (RL). Being the sensory analysis, $\%$ of humidity and electrical conductivity used to measure the quality of the drink, and other tests to determine the seeds' physiological quality.

The humidity level was assessed during the drying process, using the portable device Gehaka.

The parchment of the samples destined to electrical conductivity, germination, and vigor was mechanically removed and the parchment of the samples used for the sensory analysis was removed in the manual coffee peeler.

The coffee beverage sensory analysis was performed by trained tasters and qualified as Certified Judges of Specialty Coffee (SCAA Certified Cupping Judges), which belong to the staff of Coocafé (Coffee Producer Association) of the Region of Lajinha. The samples were prepared, codified, and sent to the lab. The roasting and sensory analysis of the samples was performed according to the methodology proposed by the 
Specialty Coffee Association of America - SCAA (LINGLE, 2011). In each evaluation, five cups of coffee were tasted, representing each sample, to which scores from 0 to 10 were attributed for each one of the following attributes: fragrance/smell, uniformity, absence of defects, sweetness, flavor, acidity, body, finalization, balance, and global impression. The final score represented the sum of the attributes. Each process was individually evaluated.

To assess the electrical conductivity, 50 beans of each experimental unit were weighted, placed in plastic cups with $75 \mathrm{ml}$ of deionized water, and stored in a BOD chamber under a temperature of $25^{\circ} \mathrm{C}$ for 24 hours. The reading was made through a conductivity meter, whose electrodes were plunged into the soaking water. Its results were expressed in $\mu \mathrm{S} . \mathrm{cm}^{-1} \cdot \mathrm{g}^{-1}$ (PRETE, 1992).

The percentage of germination was conducted with four repetitions of 50 seeds without parchment, using paper towel rolls (germitest) as substrate, with three leaves soaked with a great amount of distilled water equivalent to three times the weight of the dry substrate, and placed in a germinator under the temperature of $30{ }^{\circ} \mathrm{C}$. The evaluation was performed 15 and 30 days after the seeding, according to the Rules for the Analysis of Seeds (BRASIL, 2009).

We considered germinated the seeds which at the first count (15th day after sowing) showed protrusion of the radicle. On the 30th day after sowing, the percentage of germination was evaluated and the result expressed in normal seedlings $\%$.

The vigor test was conducted with four repetitions of ten seeds without parchment, using paper towel rolls (germitest) as substrate, with three leaves soaked with a great amount of distilled water equivalent to three times the weight of the dry substrate, and placed in a germinator under the temperature of $30{ }^{\circ} \mathrm{C}$. The evaluation was performed 30 days after the seeding, according to the Rules for the Analysis of Seeds (BRASIL, 2009).

The radicle's length was used as an indicative of the seeds' vigor. To that end, we employed the same seedlings evaluated in the vigor test. The normal seedlings were separated, and their radicle's length was measured. The result was expressed by the average length $(\mathrm{mm})$ of the normal seedlings' radicle.

As a seed vigor indicative, we employed the variables Total Fresh Mass, Total Dry Mass, and Radicle Length. The Total Fresh Mass (TFM)
CARMO, K. B. et al.

was determined 30 days after the seeding, when the normal seedlings hypocotyl-radicle were weighted in a precision scale, stored in paper bags, and dried in a forced air circulation muffle at $120{ }^{\circ} \mathrm{C}$ for 48 hours. After this period, the Total Dry Mass (TDM) was determined, which was expressed in grams.

The data were submitted to normality tests (Lilliefors) and homoscedasticity (Barttlet) tests proposed for the analysis of variance. All variables were submitted to regression analyses, and the coefficient of determination and their level of significance ( $\mathrm{P}$ Value) were used as choice criteria. An " $\alpha$ " equal to 0.05 was adopted for all procedures. All statistical analyses were performed with the assistance of the programs Assistat 7.7 (SILVA; AZEVEDO, 2016) and Sisvar 5.6 (FERREIRA, 2014).

\section{RESULTS AND DISCUSSION}

The results of the water level during processing, of the beverage, the scores, and the coffee beverage attributes submitted to different biological fermentation times are presented in Table 1.

It was verified that all the treatments presented a water content between 10.9 and $11.4 \%$ (Table 1). Green coffee must have maximum moisture of $12.5 \%$ (KOBLITZ, 2011). All samples did not reach the maximum limit stipulated by Brazilian legislation, of $12.5 \%$ (BRASIL, 2009), thus presenting the desired quality.

For the score variable, considering the score scale for the sensory evaluation of specialty coffee proposed by the Specialty Coffee Association of America (SCAA), coffee samples with scores between 80 and 84 are considered very good and are classified as specialty coffee. From all treatments, the biological fermentation of 18 hours in water resulted in the greater score, with 84 points, achieving a greater market value. Although there are not great differences between the scores, this was the best biological fermentation time of the experiment.

The body attribute varied according to the fermentation time: the longer the coffee is fermented, the less body it has. The treatments with lower scores got less body and, consequently, resulted in hard beverage coffee samples. The samples with an intense body usually receive a high score in terms of quality due to the presence of more solids dissolved in the beverage. Nonetheless, thick or light body beverages can receive a high score, even if their intensities are very different (SCAA, 2008). 
In Table 1, we notice that the sweetness attribute was good and pleasant. In the treatments of 30 and 36 hours of fermentation, they presented a green astringency caused by the excess of fermentation. We noticed that the membranes were deconstituting, resulting in the loss of the beans characteristics. Sweetness refers to the pleasant sweet taste, whose perception is the result of the presence of carbohydrates. The opposite of sweetness, for the coffee beverage, is astringency or "green" tastes, and bitterness (SCAA, 2008).

In relation to the sweetness attribute, it is noticed that it was good and pleasant (Table 1). In the treatments of 30 and 36 hours of fermentation, they presented a green astringency caused by the excess of fermentation. We noticed that the membranes were deconstituting, resulting in the loss of the beans characteristics. Sweetness refers to the pleasant sweet taste, whose perception is the result of the presence of carbohydrates. The opposite of sweetness, for the coffee beverage, is astringency or "green" tastes, and bitterness (SCAA, 2008).

With regard to acidity, the coffe presented a medium citric acidity with 18 hours of fermentation, which is a characteristic of specialty coffee beverages and differentiate it from the other treatments, receiving a greater score in the sensory analysis, with 84 points. Acidity is a sensory property of substances such as chlorogenic, citric, malic, and tartaric acids, which produce an acid taste. Acidity may or may not be desirable depending on the acid present in the beverage. When pleasant, it contributes for the coffee's vivacity, increases the perception of sweetness, and grants a characteristic of fresh fruit. Coffee beverages of extremely low acidity levels do not have sufficient attributes to obtain a higher score (SCAA, 2008).

Table 1. Results obtained by the sensory analysis: water level \%, beverage, and attributes of the beverage submitted to different times of biological fermentation

\begin{tabular}{|c|c|c|c|c|}
\hline Treatments & $\begin{array}{l}\text { Water level } \\
\%\end{array}$ & Beverage & Score & Attributes \\
\hline 0 hours & 11.4 & Soft beverage & 83 & $\begin{array}{l}\text { Full body, good sweetness, } \\
\text { medium acidity. }\end{array}$ \\
\hline 6 hours & 11.3 & Soft beverage & 82 & $\begin{array}{l}\text { Dense body, pleasant sweetness, } \\
\text { medium acidity. }\end{array}$ \\
\hline 12 hours & 11.1 & Soft beverage & 83 & $\begin{array}{l}\text { Full body, good sweetness, } \\
\text { medium acidity. }\end{array}$ \\
\hline 18 hours & 11 & Soft beverage & 84 & $\begin{array}{l}\text { Full body, pleasant sweetness, } \\
\text { citric medium acidity. }\end{array}$ \\
\hline 24 hours & 10.9 & Soft beverage & 82 & $\begin{array}{l}\text { Dense body, pleasant sweetness, } \\
\text { medium acidity. }\end{array}$ \\
\hline 30 hours & 10.9 & Hard beverage & 80 & $\begin{array}{l}\text { No body, good sweetness, medium } \\
\text { acidity, green astringency. }\end{array}$ \\
\hline 36 hours & 10.9 & Hard beverage & 81 & $\begin{array}{l}\text { Dense body, good sweetness, } \\
\text { medium acidity, green astringency. }\end{array}$ \\
\hline
\end{tabular}

The electrical conductivity (EC) had a better value $\left(195.7 \mu \mathrm{S} \mathrm{cm} \mathrm{g}^{-1}\right)$ after 13.3 hours of fermentation (Figure 1). The treatment with 12 hours of fermentation had the lower EC $(196.18 \mu \mathrm{S}$ $\mathrm{cm}^{-1} \mathrm{~g}^{-1}$ ) and the greater EC with 36 hours of fermentation (284.24 $\mu \mathrm{S} \mathrm{cm}^{-1} \mathrm{~g}^{-1}$ ) (Figure 1).

Notice that the score of 81 points (Table 1) was achieved after 36 hours of fermentation, which had the greater EC values. These data agree with Goulart et al. (2003), who report that the electrical conductivity values are inversely proportional to the quality decrease of the evaluated coffee samples.

It is observed that the two major low values of EC (Figure 1) resulted in coffee samples from hard drinks (Table 1). According to Goulart et al.
(2003), the electrical conductivity can be employed to classify coffee samples as strictly soft, soft, and barely soft beverages and as hard, Rio, and Rioysh beverages. These authors cite that the values of electrical conductivity increase with the depreciation of the quality of the analyzed coffees. With the rupture of the cells, takes place an extravasation of cellular content (enzymes, proteins, amino acids, carbohydrates, lipids, ions, etc.) fact this that cause numerous undesirable random reactions.

We can notice that, after 24 hours of fermentation, the treatments decrease the beverage's quality from soft to hard, increasing the beans electrical conductivity. 


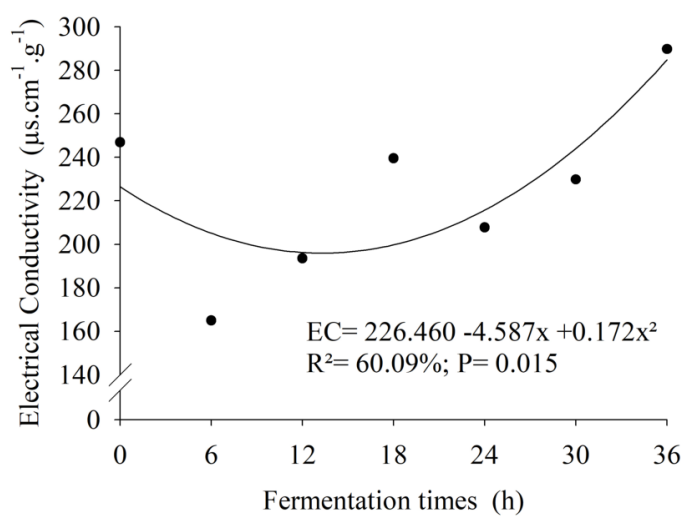

Figure 1. Electrical Conductivity (EC) of coffee beans submitted to different fermentation times in water.

According to Figure 2, we can observe that for the first germination count (FCG) the lowest value $(91.94 \%)$ was expressed at 21.85 hours of fermentation. At zero hour of fermentation it showed a higher percentage of germination $(94.94 \%)$, and the lowest value $(91.1 \%)$ was expressed at 24 hours of fermentation.

According to the Rules for Seed Analysis Brazil (2009) it is recommended to carry out the

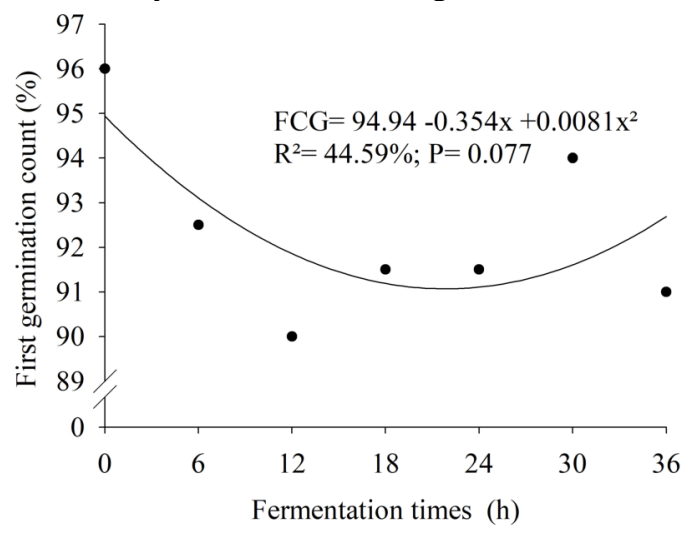

first count of coffee seeds after 15 days. However, the FCG test did not demostrate being adequate at 15 days, probably the radicular variable size at 15 days of life is not sufficient to represent the vigor of the seed, with a discrepancy for the 15-day evaluation (FCG) and the evaluation performed at 30 days (TG), showing that some seeds did not develop (Figure 3). Noting that for evaluation of vigor we should adopt evaluation at 30 days.

Figure 2. First germination count (FCG) of coffee seeds submitted to different fermentation times in water.

The percentage of germination $(\% \mathrm{G})$ (Figure 3) presented its best result $(83.73 \%)$ at 17.22 hours of fermentation. The lowest germination value $(49.67 \%)$ was found at 36 hours of fermentation and the highest value $(69.02 \%)$ at 18 hours of fermentation.

It is observed that the fermentation favored germination within 17.22 hours, after that there was a reduction in the values of germination. This reduction of germination may have occurred probably due to the time of exposure of the seeds in water, rupturing the cell membranes releasing exudates and metabolizing compounds. As shown in Figure 1, the highest EC values correspond to the lowest percentage of germination (Figure 3). High CE values indicate that the seeds lost cellular contents and present large amounts of leachate, being classified as "medium or low vigor" seeds and seeds with low EC values are classified as "high vigor" (VIEIRA, 1994; VIEIRA; KRZYZANOWSKI, 1999).

Motta (2001), however, observed improvements in coffee seed quality from the second day of hydration. Lima et al. (2003) found that immersion in water for 34 hours increased seed germination by $41 \%$ for 90 days. However, Altoé et al. (2003) observed greater treatment efficiency when using 21 and 27 hours of duration for arabica and conilon coffee seeds, respectively.

It was also verified in Figure 3 that the lowest germinations were obtained by the seeds belonging to the treatments of 0 and 36 hours of 
fermentation, with less than $50 \%$ of germination, outside the pattern of commercialization of seeds. germination for the production and The other treatments presented above-standard commercialization of seeds and coffee seedlings, which is 50\% (CETCAF, 2016).

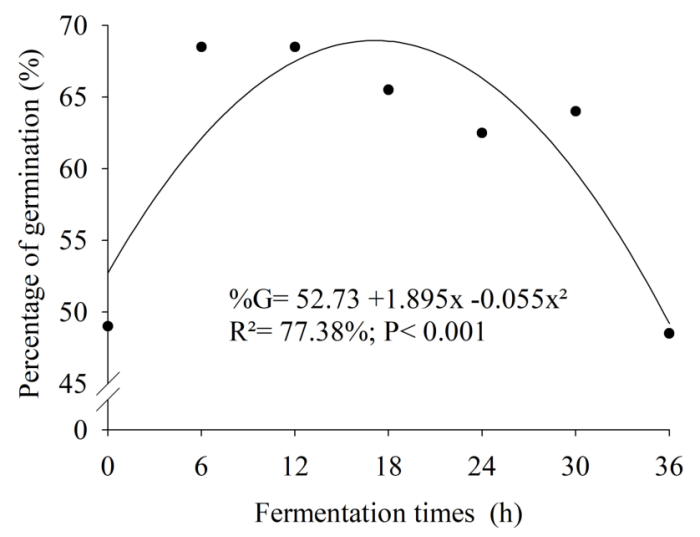

Figure 3. Percentage of germination $(\% \mathrm{G})$ of coffee seeds submitted to different fermentation times in water.

For total fresh mass (TFM) (Figure 4) there was an increase up until 18.57 hours of fermentation presenting a better value $(0.11 \mathrm{~g})$. The lowest value was observed at zero hour $(0.068 \mathrm{~g})$ and the highest value at 18 hours of fermentation $(0.116 \mathrm{~g})$. The best fermentation time for MFT was also the best time to obtain a higher percentage of germination.

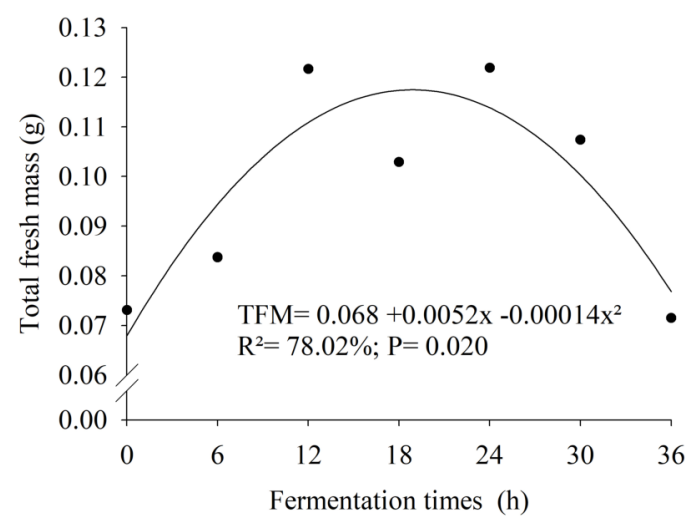

Figure 4. Total fresh mass (TFM) of coffee seeds submitted to different fermentation times in water.

In Figure 5, we can observe that the mass of total dry mass (TDM) increased, reaching its best value $(0.017 \mathrm{~g})$ after 17.36 hours of fermentation. Its highest value (0.017) was obtained after 18 hours of fermentation and its lowest value $(0.010 \mathrm{~g})$ after 36 hours.

Greater exposure periods facilitate the entrance of water in the seeds, speeding the storage degradation processes up, and allowing the liberation of exudates and reducing the radicle's mass after 18 hours of fermentation. Nevertheless, the entrance of water in the integument facilitates the germination to some extent. Notice that the treatment with greater TDM and TFM values is the same treatment of greater percentage of germination.

The determination of the dry mass is a way to assess the seedling's growth, since there is a transfer of the storage tissue dry mass to the embryonic axle (NAKAGAWA, 1999). 


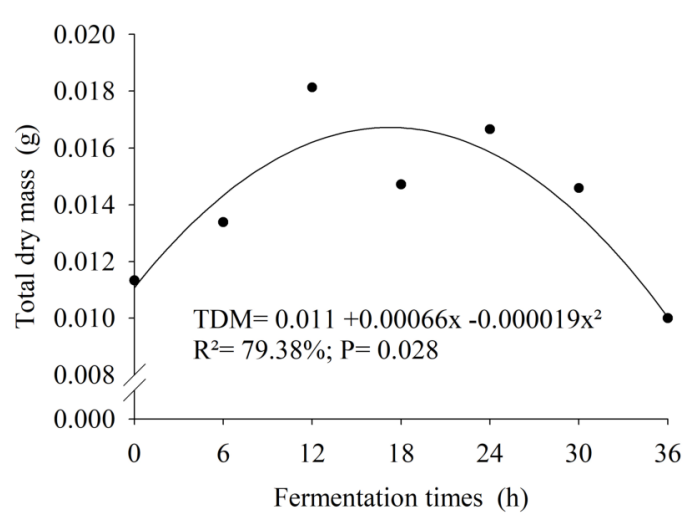

Figure 5. Total dry mass (TDM) of coffee seeds submitted to different fermentation times in water.

For the radicle length variable (Figure 6), increasing radicle behavior up to 18 hours of fermentation $(38.17 \mathrm{~mm})$ was observed. After 18 hours of fermentation the length started decreasing, with the lowest value $(21.61 \mathrm{~mm})$ being observed at zero fermentation hour and the highest value $(38.14$ $\mathrm{mm})$ at 18 hours. It is worth pointing out that the best fermentation time for radicle length (18 hours) was also the best fermentation time for percentage of germination; TFM and TDM.
The length of seedlings can be used as a criterion to distinguish the vigorous from the nonvigorous ones because vigorous seeds originate seedlings with greater growing rates due to their greater transformation capacity, storage tissue nourishment supply, and to the greater incorporation thereof by the embryonic axis (DAN et al., 1987).

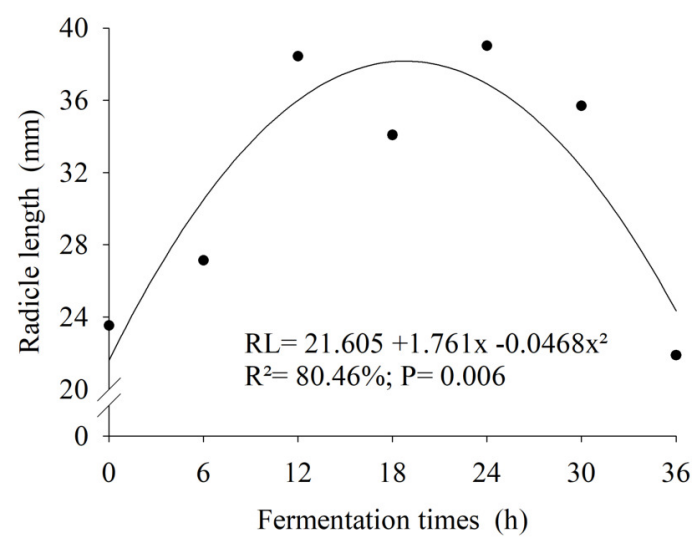

Figure 6. Radicle length of coffee seeds submitted to different fermentation times in water.

We can observe in Table 1 that the highest score was 84 points at 18 hours of fermentation, the fermentation time being very close to the value for the best percentage of seedlings. Emphasizing that the sensorial quality is related to the percentage of normal seedlings. This implies the use of quality seeds in nurseries for the production of seedlings. According to Borém (2008), the removal of the exocarp from the fruit usually results in better quality coffee drink. This statement corroborates the results found by Saath (2010), whose samples of better sensory quality also presented higher percentage of germination and lower values of electrical conductivity. As observed in this study, the production of coffee beans of higher sensory and physiological quality is strongly related, and the reduction in drink quality can be detected by the physiological tests. This explains the high relation obtained between the results of the sensorial and physiological analyzes of the coffee beans.

The treatments with better quality scores and lower electrical conductivity resulted in a higher percentage of germination. In the case of seeds, the increase of electrical conductivity is accompanied by loss of vigor and germination potential, being, therefore, a method used to infer grain deterioration processes (VIEIRA et al., 2001). Borém. (2008) and Coradi et al. (2007) claim that the extravasation of solute from the cells interior due to disorganization or rupture of the cytoplasmic membranes may favor oxidative reactions or catalytic reactions giving products that are undesirable and harmful to the sensorial quality of the coffee. The loss of the selective permeability of the cell membranes allows chemical components, previously compartmentalized, to come into contact with 
hydrolytic and oxidative enzymes, altering the chemical composition of the beans and, consequently, the flavor and aroma of the coffee beverage by triggering biochemical reactions of several orders (MARQUES et al., 2008).

\section{CONCLUSIONS}

The fermentation allows to add quality to the sensorial quality;

Fermentation with water for a period of 18 hours resulted in better results both in the sensorial analyzes and in the physiological quality of the coffee seeds, resulting in greater germination and vigor.

RESUMO: O valor do café tem um aumento significativo com a melhoria da qualidade dos grãos, um café com grãos de qualidade inferior tem uma aceitação inferior no mercado e uma redução no valor de comercialização. Os diferentes tempos de fermentação do café em água podem originar diferentes bebida e qualidade fisiológica de suas sementes, podendo interferir no valor na comercialização e na produção de mudas em viveiros. O objetivo desse trabalho foi identificar o melhor tempo de fermentação dos grãos e sementes de café Arábica da região de Mutum-MG, visando obter melhor qualidade da bebida e qualidade fisiológica das sementes. $\mathrm{O}$ delineamento experimental utilizado foi inteiramente casualizado, com sete tratamentos, $0,6,12$, $18,24,30$ e 36 horas de fermentação em água. Foram utilizadas quatro repetições por tratamento. Cada repetição foi constituída por dez litros de café. As amostras passaram por processo de secagem em terreiro suspenso coberto até atingir $12 \%$ de umidade. As avaliações consistiram na realização da análise sensorial (AS); \% teor de água (\%U); condutividade elétrica (CE); primeira contagem de germinação (PCG); porcentagem de germinação $(\mathrm{G})$; massa fresca total (MFT); massa seca total (MST) e comprimento de raiz (CR). O tempo de fermentação de 18 horas proporcionou melhor qualidade de bebida de café obtendo nota de 84 pontos e também resultou em maior qualidade fisiológica das sementes. A fermentação em excesso prejudicou a qualidade da bebida e a qualidade fisiológica.

PALAVRAS-CHAVE: Pós-colheita. Bebida; Cafés especiais.

\section{REFERENCES}

ALTOÉ, M. et al. Qualidade de sementes dos cafés do estado do Espírito Santo após diferentes períodos de embebição. Informativo ABRATES, Gramado, set. 2003, v. 13, n. 3, p. 155.

APARECIDO, L. E. O.; ROLIM, G. S.; SOUZA, P. S. Sensitivity of newly transplanted coffee plants to climatic conditions at altitudes of Minas Gerais, Brazil. Australian Journal of Crop Science, Queensland, v. 9, n. 2, p. 160-167, 2015.

AVALLONE, S.; GUYOT, B.; BRILLOUET, J.; OLGUIN, E, GUIRAUD, J. Microbiological and biochemical study of coffee fermentation. Current Microbiology, v.42, p.252-256, 2001.

https://doi.org/10.1007/s002840110213

AVALLONE, S.; BRILLOUET, J.M.; GUYOT B.; OLGUIM, E.; GUIRAUD, J.P. Involvement of pectolytic micro-organisms in coffee fermentation. Journal of food science and technology, London, v.37, p. 191-198, 2002. https://doi.org/10.1046/j.1365-2621.2002.00556.x

BORÉM, F. M. Pós-colheita do café. Lavras: UFLA, 2008, v.1, p.631.

BRASIL. Ministério da Agricultura, Pecuária e Abastecimento. Regras para Análise de Sementes. Ministério da Agricultura, Pecuária e Abastecimento. Secretaria de Defesa Agropecuária. Brasília, DF: Mapa/ ACS. 2009, p. 395.

Centro Nacionale de Investigación de Café - CENICAFÉ. Avanços técnicos, Programa de Investigación

Científica Fondo Nacional del Café, abril de 2015. Disponível em:

<http://www.cenicafe.org/es/publications/avt0454.pdf>. Acesso em: junho de 2018. 
CETCAF. Normas padrões e procedimentos para produção de sementes e mudas de café, 2016.

Disponível em: http://www.cetcaf.com.br. Acessado em: 6 de dezembro de 2017.

CONAB - Companhia Nacional de Abastecimento. Acomp. safra bras. café.Safra 2017. Segundo Levantamento, Brasília, p. 1-108 vol. 4, n.2, maio. 2017. Disponível em:<http://www.conab.gov.br/OlalaCMS/uploads/arquivos/17_05_18_15_37_37_boletim_cafe__maio_2017.pdf> Acesso em: 14 novembro de 2017.

CORADI, P. C. et al. Effect of drying and storage conditions on the quality of natural and washed coffee. Coffe Science, Lavras, v. 2, n. 1, p. 38-47, Jan./June 2007.

DAN, E. L.; MELLO, V. D. C.; WETZEL, C. T.; POPINIGIS, F.; SOUZA, E. P. Transferência de matéria seca como método de avaliação do vigor de sementes de soja. Revista Brasileira de Sementes, Brasília, v. 9, n. 3, p. 45-55, 1987.

DIAS, M.C.L.L.; BARROS, A.S.R. Avaliação de métodos para remoção da mucilagem de sementes de café (Coffea arabica L.). Revista Brasileira de Sementes, Brasília, DF, v.15, n.2, p.191-195, 1993. https://doi.org/10.17801/0101-3122/rbs.v15n2p191-195

FERREIRA, D.F. Sisvar: a guide for its bootstrap procedures in multiple comparisons. Ciência e Agrotecnolgia, Lavras, v. 38, n. 2, p. 109-112, 2014. https://doi.org/10.1590/S1413-70542014000200001

GIOMO, G. S. Uma boa pós-colheita é o segredo da qualidade. A Lavoura, Rio de Janeiro, v. 115, n. 688, p.12-21, 2012.

GOULART, P. F. P.; ALVES, J. D.; MALTA, M. R.; MAGALHÃES, M. M.; PEREIRA, R. G. F. A.; MEYER, L. E. Análise comparativa entre lixiviação de potássio, condutividade elétrica, teor de ácido clorogênico e métodos de quantificação da atividade da polifenol oxidase em extratos semipurificados de amostras de café de diferentes padrões de qualidade. Revista Brasileira de Armazenamento, Viçosa, Especial café, n. 7, p. 78-85, 2003.

ISQUIERDO, E. P.; BORÉM, F. M.; CIRILLO, M. A.; OLIVEIRA, P. D.; CARDOSO, R. A.; FOTUNATO, V. A. Qualidade do café desmucilado submetido ao parcelamento da secagem. Coffee Science, Lavras, v. 6, n. 1, p. 83-90, 2011.

KOBLITZ, M. G. B. Matérias primas alimentícias: composição e controle de qualidade. Rio de Janeiro: Guanabara Koogan, 2011.

LIMA, W. A. A. et al. Controlled hydration for priming in coffee (Coffea arabica L.) seeds. Seed Science and Technology, Zurich, v.31, n.1, p. 29-37, 2003. https://doi.org/10.15258/sst.2003.31.1.04

LIMA, M. V.; VIEIRA, H. D.; MARTINS, M. L. Perfil do pH do meio durante a de gomagem de grãos de café. Bragantia, v. 68, n.1, p. 251-255, 2009. https://doi.org/10.1590/S0006-87052009000100027

LINGLE, T. R. The coffee cupper's handbook: systematic guide to the sensory evaluation of coffee's flavor. Long Beach: Specialty Coffee Association of America, 2001.

MALTA, M. R. CHAGAS, S. J. R.; CHALFOUN, S. M. Colheita e pós-colheita do café: recomendações e coeficientes técnicos. Informe Agropecuário, v.29, n.247, p.83-94, 2008.

MALTA, M. R. Critérios utilizados na avaliação da qualidade do café. Informe Agropecuário, v.32, n.261, p.114-126, 2011. 
MARQUES, E. R. et al. Eficácia do teste de acidez graxa na avaliação da qualidade do café arábica (Coffea arabica L.) submetidos a diferentes períodos de temperatura e pré-secagem. Ciência e Agrotecnologia, Lavras, v. 32, n. 5, p. 1557-1562, set./out. 2008. https://doi.org/10.1590/S1413-70542008000500030

MATIELLO, J. B. O café: do cultivo ao consumo. São Paulo: Globo. p. 387, 2002.

MOTTA, C. A. P., Recuperação da viabilidade de sementes de café após tratamentos de hidratação e desidratação. Ciência e Agrotecnologia, Lavras, v.25, p.1142-1149, 2001.

NAKAGAWA, J. Testes de vigor baseados no desempenho das plântulas. In: KRZYZANOSKI, F.C.; VIEIRA, R.D.; FRANÇA NETO, J.B. (Ed.). Vigor de sementes: conceitos e testes. Londrina: ABRATES, p.2.1-2.24. 1999.

NEY, S.; MARTINEZ, H.; TOMAZ, M.; BORÉM, A. Café arábica - do plantio à colheita. 316p, 2015.

PRETE, C. E. C. Condutividade elétrica do exsudato de grãos de café (Coffea arabica L.) e sua relação com a qualidade da bebida. 1992.125p. Tese (Doutorado em Fitotecnia) - Escola Superior de Agricultura Luiz de Queiroz, Piracicaba. 1992.

REIS, P.R.; CUNHA, R. da L. Café Arábica do plantio à colheita, 895 p. 2010.

SAATH, R. Qualidade do café natural e despolpado em diferentes condições de secagem e tempos de armazenamento. 2010. 229 p. Tese (Doutorado em Agronomia) - Universidade Estadual Paulista, Botucatu, 2010.

SCAA. SPECIALTY COFFEE ASSOCIATION OF AMERCIA-Protocolo para Análise Sensorial de CaféMetodologia SCAA. Doc. V- Portuguese. Rev. December, 2008.

SELMAR, D., BYTOF, S., KNOPP, E., BREITENSTEIN, B. Germination of Coffee Seeds and its Significance for Coffee Quality. Short Research Paper. Plant Biol. v. 8, p. 260-264. 2006. https://doi.org/10.1055/s-2006923845

SILVA, F. A. S.; AZEVEDO, C. A. V. The Assistat Software Version 7.7 and its use in the analysis of experimental data. African Journal of Agricultural Research, v. 11, n. 39, p. 3733-3740, 2016. https://doi.org/10.5897/AJAR2016.11522

VIEIRA, A. H. et al. Técnicas de produção de sementes florestais. Porto Velho: Embrapa, 2001.

VIEIRA, R. D.; KRZYZANOWSKI, F. C. Teste de condutividade elétrica. In: KRZYZANOWSKI, F. C., VIEIRA, R. D., FRANÇA NETO, J. B. (Ed.). Vigor de sementes: conceitos e testes. Londrina: ABRATES, 1999. p. 4-1 a 4-26.

VIEIRA, R. D.; PAIVA A., J. A.; PERECIN, D. Electrical conductivity and field performance of soybean seeds. Seed Technology, v. 21, n. 1, p. 15-24, 1999. 